\title{
Is Islamic Banking in Turkey really interest-free?
}

\author{
HARUN ERCAN $^{1 *}$ (D) ILHAMI KARAHANOGLU ${ }^{2}$ and GYÖRGY WALTER ${ }^{1}$
}

${ }^{1}$ Department of Finance, Corvinus University of Budapest, Budapest, Hungary

${ }^{2}$ Law Department, Ankara University, Ankara, Turkey

Received: June 4,2020 • Revised manuscript received: September 15, 2020 • Accepted: June 29, 2021

Published online: August 31, 2021

(c) 2021 The Author(s)

\begin{abstract}
Islamic Finance receives more attention due to the growing need for financial services in countries with a Muslim population. However, the rules of Islam and its applications in daily life cause conflicts in today's conventional financial system. Since interest gains are prohibited in Islam according to the Quran, Islamic banks develop and use interest-free methods, unlike the conventional banking system. Islamic Finance introduced profit-sharing ratios to replace interest rates and to increase the participation of religious investors in the financial system. In this research, we compare interest rates with profit-sharing ratios in the Turkish banking market. We use wavelet and historical correlation analysis as a new methodology in evaluating the association between these two factors. Although it is presumed that Islamic banks operate as interest-free banks, our analysis confirms former studies and finds that profit-sharing ratios are highly correlated and coherent with interest rates in Turkey. We also find small differences among Islamic banks on how quickly profit-sharing ratios follow the market interest rate changes.
\end{abstract}

\section{KEYWORDS}

Islamic finance, banking, wavelet, correlation, profit-loss sharing, Turkey

JEL CODES

G21, E44, F30

\section{INTRODUCTION}

According to Islamic law or Shariah, all activities in a Muslim's life should align with the teachings of the Quran. Transactions based on Riba (interest or usury), which is the

\footnotetext{
*Corresponding author. E-mail: harunerc@gmail.com
} 
predetermined return on the use of money, is forbidden in Shariah. Islamic finance has two principles: interest-free banking and risk-sharing. Since Islamic law prohibits collecting interest, which is used in conventional banking, Islamic Finance has created an ex-post rate on a "profitloss sharing" basis (PLS) in financial contracting. As offering a pre-determined ex-ante fixed rate of return to the depositors is prohibited, unlike conventional banking, Islamic banking replaced interest rates with an assumed uncertain rate of return of specific transactions.

The demand for Islamic banking in the Turkish Banking Sector is growing for various reasons, and the share of Islamic banks, also called participation banks, has been increasing rapidly. Islamic banking assets in Turkey have doubled in the last decade, while regulations and government policy encourage the sector to expand further (Moody's 2020). Due to the growing demand and supply, the future of the finance sector can be impacted by changes in investor decisions. As investors' decisions are largely influenced by compliance with the Islamic law, the potential correlation between profit-sharing ratios and interest rates may increase the doubts of religious participators and harm trust in Islamic banking. These doubts can potentially cause a decline in demand for the services of Islamic banks among religious investors and clients.

We focus our analysis on the relationship between profit shares and interest rates in the Turkish financial market. Our study aims to identify the relationship between the profit-sharing ratios of participation banks and the average interest rates applied to banks' deposits in the Central Bank of Turkey. To investigate the possible association, the data of five Turkish participation banks and the Central Bank are analyzed. The research is based on a recent database between 2016 and 2019 with a quantitative methodology that has not yet been used in this field. Our study investigates the relationship using two different methodologies, comparing the results, and providing an explanation. Conclusions can serve as a guideline for participation bank investors who want to avoid the accusation of using a 'quasi interest rate' which is prohibited in the Quran. Our results could also be useful for investors searching for new opportunities in the banking market, as well as for governments, which support capital inflow into the sector.

In the next sections, we first present the main characteristics of Islamic banking rules, and relevant banking products. We provide a literature review of the studies made on the relation of PLS and interest rates. We present a summary explaining the importance of Islamic banking in Turkey, then we explain the data and methodologies used in the paper. Finally, we discuss our findings.

\section{LITERATURE REVIEW}

In Islamic Banking profit-loss sharing typically appears in different modes of financing. Banks could provide loans via purchasing a commodity or a service and resell them at a future date, based on cost and markup ('Murabaha method'). Banks can also offer profit-loss sharing investment contracts, similar to a joint venture ('Musharakah method'), sharing the profit based on the proportion of their participation that could change over time. There are other similar types of transaction (like ljara, istisna, salam securities, bay' al-fuduli, 'inah and tawarruq, bay' al-'uhdah) described in the literature of Islamic Finance (El Gamal 2006). These procedures are regarded to be consistent with the guidelines of Islam (Khan 1986; Dar - Presley 2000).

Some papers concluded that, as Islamic banks had higher credit risks in their operations, therefore they tended to charge a higher return on these products than conventional banks. This 
risk premium must compensate for the extra risk identified in the Islamic banking operation (e.g. Ahmad - Ahmad 2004; Warninda et al., 2019). However, these studies did not present a quantitative methodology to specify and calculate the assumed extra credit risk premium. Other researchers focused more on the operational differences between Islamic banking and conventional banks, as a cause of higher credit risk. They concluded that Islamic banks faced higher risks than conventional banks due to conflicts between their applied methods of handling credit risk and rules of Sharia (Elgari 2003; Ferhi 2018) There is a limited possibility for managing credit risk in Islamic banks, due to how Islamic rules relate to financial transactions. For instance, the use of haram goods, i.e. those forbidden by Islam, or interest-bearing securities as collateral is not allowed (Khan - Ahmed 2001).

The papers which focused on interest rate differences of commercial banks and profit shares of participation banks can be classified into two main groups with two different perspectives. The first perspective concentrated on the direct relationship between interest rate and profit shares. These papers examined the co-movement of the two rates and generally applied the conventional correlation, conditional or dynamic correlations, and VAR methodology. Zineldin (1990) claimed that Islamic banks focused on financing short-term projects with higher returns and lower risks instead of high-risk high-return projects. Houssain (2002) focused on the profits and analyzed the correlation between interest rate and profit share ratio. He showed that there was a weak association between those rates. Other papers applied different methods to find out the relationship between those two variables. Their results showed either very weak or no associations in their country-based analysis (Athanasoglou et al., 2006; Vong and Chan 2006; Bashir 2001). Chong and Liu (2009) investigated the returns of Malaysian Banks and their deposit accounts. Their findings showed that the returns on conventional banking deposits and Islamic bank deposits resembled due to competitive reasons. In conclusion, the profit-sharing ratios in Malaysia were not different from conventional banks' interest rates.

The second group analyzed the relationship through different factors and for different purposes. The main objective was not only to investigate the relationship but also to illustrate possible contagion between interest rates and profit shares. Anuar et al. (2014) showed that Islamic banks were the alternative investment instruments against commercial banks by comparing their returns for a limited period through conditional correlations. Latifa et al. (2018) and Chen and Masih (2017) used the same approach to show the variation spillover effect between those rates. In their analysis, they showed a dynamic correlation between those markets. However, these analyses were criticized due to the short period and a limited number of observations. Koufi (2018) applied the same methodology but used a longer period with more observations. He also concluded that the conditional correlation between the returns of conventional and Islamic banks increased during the financial crisis in Malaysia. The findings implied that a financial contagion effect between Islamic and conventional banks did exist. Other papers analyzed whether the commercial banks' interest rate could be replaced by the Islamic profit share rate as an alternative investment. Azamat et al. (2015; 2020), Sorwar et al. (2016) and Azad (2018) proposed that Islamic banking could be an alternative for commercial banks under certain circumstances. They used either classical correlation or conditional correlation models.

We only found one paper following a wavelet analysis between commercial bank interest rates and participation (Islamic) banks' profit share ratio. In his research, Shaukrat (2014) showed that profit shares were closely pegged to conventional deposit rates in Malaysia between 2005 and 2011. 
The literature about critiques of profit-sharing in Islamic Finance in Turkey, analyzing its relation to an interest rate environment, is limited. These studies of the Turkish banking system mainly supported the idea that profit-sharing ratios of participation banking were correlated with interest rates of conventional banks, and participation banks showed high similarities to the conventional banking sector. Ergec and Arslan (2011) employed the VAR method to observe the impact of shocks on the participation and conventional banks in the Turkish banking system. They found that an increase in the interest rate affected both conventional and participation banks. Saraç and Zeren (2015) found evidence to support the view that profit share ratios of participation banks were highly correlated with the interest rates of conventional banks in Turkey. Yllmaz and Gunes (2015) compared the efficiency of the two banking sectors with the data envelopment method, and they found a similarity.

Dinç (2016) researched the institutional difference between commercial and Islamic banks in Turkey and found a close homogeneity. He concluded that the Islamic banks in Turkey had the same management process and organizational structures with similar internal procedures, the same risk appetite, and competitive actions as well when compared to commercial banks. Dinç (2017) illustrated the impact of inflation on the net profit margin of participation banks and found that the correlation was high between profit share, interest, and inflation rate. Yuksel et al. (2017) also analyzed the Turkish banking system and found a high degree of causality between interest rates and profit shares. Koc (2018) examined the relationship between the conventional banks' interest rates and profit shares of four Turkish participation banks. Based on a seemingly unrelated regression analysis of the data of 2005-2016, he argued that the profit-sharing ratios of the participation banks were associated with interest rate changes. On the other hand, the study also concluded that the level of the relationship was not the same for all banks. Aysan and Ozturk (2018) focused on the co-movement or tactical/strategic behavioral similarity between conventional commercial banks and the Turkish Islamic banks. They found that they had a similar risk and profit appetite and followed the same pattern as other banks concerning credit expansion and recession politics.

The existing literature mostly supports the idea that profit-sharing ratios were correlated to the interest rate in conventional banking. We contribute to the literature in two ways. First, we take the data of the latest time period in which participation banks have gained a considerably larger market share in Turkey. Second, we use a new methodology to analyze the association.

\section{DATA AND METHODOLOGY}

According to the Main Banking Sector Indicators Report of BRSA (Banking Regulatory and Supervision Authority) in 2019 (BDDK 2019), the Turkish banking sector had 34 commercial banks, 13 development and investment, and 6 participation banks. The asset size of the Turkish banking sector was equal to the GDP of Turkey in 2018. Concerning the asset size, participation banks constituted $6.4 \%$ of the assets of the total banking sector. Regarding the assets and liability structure, about $59 \%$ of the assets were loans and $57 \%$ of the liabilities were deposits, dominantly retail deposits (67\% of total deposits).

According to the Turkish Banking Law, conventional banks and participation banks operate under the same regulations in Turkey. Albaraka Turkish Private Finance Corporation was the first Islamic bank in Turkey, founded in January 1985. The private financial institutions became 
participation banks and were subject to the Banking Law in 2005. The construction of such banks was aimed at supporting the development of interest-free banking in the country. Islamic Banking has gained more attention, mostly over the last decade, as new private and public participation banks entered the market. The total asset size of operating participation banks was 43.3 billion TL in 2010 , which increased to 284.4 billion TL by 2019 , showing the growing importance of this sector within the banking sector.

Table 1 illustrates the asset and credit shares of participation banks in the Turkish banking sector that we include in our analysis. The aggregated volume of these five Islamic banks reached more than $6 \%$ of the whole sector by the end of 2019. We exclude Emlak Katilim Bank from the analysis due to the lack of data, which has recently entered into the sector.

The data is collected over a period of 46 months, from March 2016 to December 2019. The time frame is determined by the last entrance of Vakif Katilim, which joined the system in 2016. The monthly participation rates (profit shares) of the five banks are compared to official monthly weighted average interest rates published by the Central Bank, and applied to commercial banks' deposits.

Figure 1 presents the data series of the average of participation banks' profit-sharing ratios and monthly weighted average interest rates applied to banks' deposits by the Central Bank. It shows that participation rates are lower than the interest rates applied to banks' deposits throughout the period until the end of 2019. The phenomenon that investors of the participation banks accept lower rates for their deposits can be explained by their consumer behavior shaped by religious rules (Okumus 2005). On the other hand, participation banks are expected to be transparent in showing that participation rates are different, not equivalent to interest rates.

Our study employs two different methodologies to analyze the relationship between monthly participation bank profit shares and monthly weighted average interest rates applied to banks' deposits at the Central Bank of Turkey. After presenting the simple correlation among the rates, we do a historical correlation analysis to observe the changes of correlations between the variables during the period. Then, wavelet coherence analysis is applied to see the coherence between conventional banking interest rates and participation rates. The methods complete each other and explain the relationship between the rates during the observed period from two aspects.

First, we employ a historical correlation analysis. As the number of observations is limited, multivariate GARCH models could not be applied. The following steps are employed to observe the correlations and illustrate the similarities among interest rates. The interest rate movement of the variables (banks) which have 46 observations are uploaded to the R computer program. We take the first 33 observations to calculate the first pair correlation for the two variables (banks). Then, we calculate the second correlation between the two by taking the next 33 observations (between the $2^{\text {nd }}$ and $34^{\text {th }}$ observations). This procedure is repeated 14 times between the observations. As there are 6 banks, there will be 15 pairs to produce correlations. There are 15 combinations as a result of paired observations from a set of 6 banks; therefore, the process will be repeated 15 times. All these calculations are facilitated by the correlation function and loops coded in $\mathrm{R}$.

When the frequency contents change over time, time series become non-stationary. For these time series, it is important to have a measure of correlation or consistency in the time-frequency phase. We use wavelet coherence analysis to detect time-dependent general oscillations in nonstationary signals between the central bank's deposit rates and the profit-sharing ratios of the 
Table 1. Participation banks and their shares in the Turkish Banking System (December 2019)

\begin{tabular}{|l|c|c|c|c|c|c|c|}
\hline $\begin{array}{l}\text { Name of The } \\
\text { Bank }\end{array}$ & $\begin{array}{c}\text { Settlement } \\
\text { Date }\end{array}$ & $\begin{array}{c}\text { Total Assets } \\
\text { (thousands } \\
\text { TRL) }\end{array}$ & $\begin{array}{c}\text { Total Share in } \\
\text { Participation } \\
\text { Banks }\end{array}$ & $\begin{array}{c}\text { Total Share in } \\
\text { Banking Sector }\end{array}$ & $\begin{array}{c}\text { Total Credits } \\
\text { (thousands TRL) }\end{array}$ & $\begin{array}{c}\text { Total Share in } \\
\text { Participation } \\
\text { Banks }\end{array}$ & $\begin{array}{c}\text { Total Share in } \\
\text { Banking Sector }\end{array}$ \\
\hline $\begin{array}{c}\text { Albaraka Türk } \\
\text { Participation } \\
\text { Bank }\end{array}$ & 1.1 .1984 & $51,392.37$ & $18.41 \%$ & $1.14 \%$ & $30,880.92$ & $18.12 \%$ & $1.16 \%$ \\
\hline $\begin{array}{c}\text { Kuveyt Türk } \\
\text { Participation } \\
\text { Bank }\end{array}$ & 1989 & $104,439.35$ & $37.42 \%$ & $2.33 \%$ & $57,925.97$ & $33.99 \%$ & $2.18 \%$ \\
\hline $\begin{array}{c}\text { Türkiye Finans } \\
\text { Participation } \\
\text { Bank }\end{array}$ & 28.12 .2005 & $52,427.41$ & $18.70 \%$ & $1.17 \%$ & $33,272.69$ & $19.52 \%$ & $1.25 \%$ \\
\hline $\begin{array}{l}\text { Vakıf Participation } \\
\text { Bank }\end{array}$ & 25.06 .2015 & $30,348.78$ & $10.87 \%$ & $0.68 \%$ & $18,770.50$ & $11.01 \%$ & $0.71 \%$ \\
\hline $\begin{array}{l}\text { Ziraat } \\
\text { Participation } \\
\text { Bank }\end{array}$ & 29.5 .2015 & $36,392.17$ & $13.04 \%$ & $0.81 \%$ & $29,565.03$ & $17.35 \%$ & $1.11 \%$ \\
\hline Total & & $100 \%$ & $6.12 \%$ & Total & $100 \%$ & $6.42 \%$ \\
\hline
\end{tabular}

Source: TBB 2020. 


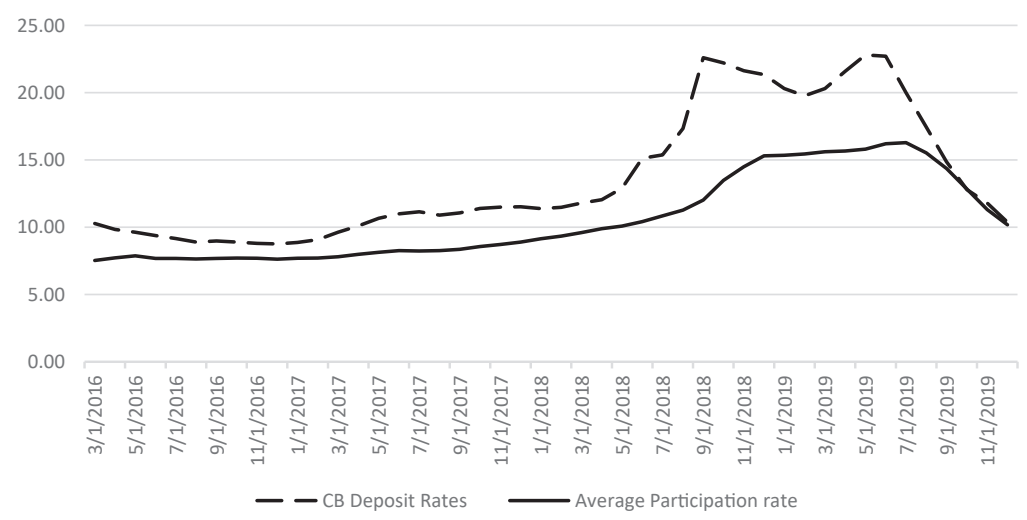

Source: TCMB and TBB web sites (2020).

Fig. 1. Average deposit interest rates in the central bank (CB) and participation bank profit rates

participation banks. Various types of wavelet techniques were used in different scientific areas due to their applicability for nonstationary processes. For example, it was also used in financial analyses when papers focused on the relation between interest rates and exchange rates (Hamrita - Trifi 2011), the relation of interest rates and stock exchange returns (Moya-Martínez et al., 2015), or the association between mortgage and GDP in Spain (González et al. 2012). The methodology was also applied for analyzing stock market returns, the relation of commodity prices, or indexes (e.g. Reboredo et al. 2017; Pal - Mitra 2017; Jiang - Yoon Min 2020). Due to possible problems of non-stationarity, the use of wavelets is beneficial in analyzing financial data where frequency behavior changes within time. The wavelet coherence analysis is a robust method for both stationary and non-stationary data when time series are influencing each other. The phase of the wavelet cross-spectrum can be used to identify the relative lag between the twotime series (Mathworks 2020), and we can uncover possible interactions without losing the time information. However, as a limitation, it is usually mentioned that the result is difficult to quantify due to the complexity of resulting patterns if the ground truth is unknown (Zhao et al. 2018). In our analysis, we calculate the squared wavelet coherence coefficient as a local linear correlation measure between two-time series (profit sharing ratios and Central Bank deposit rate) in the time-frequency space, and present the coherence magnitudes and relative phases at the time scale in figures.

\section{RESULTS AND DISCUSSION}

In this part of the study, the association between conventional banks' interest rates and participation banks' profit-sharing ratios is evaluated and results are discussed. Before applying the historical correlation and wavelet techniques, first we calculate the correlations among the participation banks' profit rates, and the correlation between profit rates and the monthly weighted average interest rates applied to banks' deposits at the Central Bank. The correlation 
coefficients among profit share rates and the correlation coefficients between the central bank interest rate and profit rates are very high, between 0.89-0.94 (see Table 2). Although the correlations illustrate the nature of the association, they do not provide enough information about the process and co-movements.

In the historical correlation analysis, the variables are the profit shares of Islamic banks and monthly weighted average interest rates applied on banks' deposits put into the Central Bank. First, we take the first 33 observations (between the first observation and the $33^{\text {rd }}$ one) to construct the first frame (frame 1). The second frame is constructed by taking the observations between the $2^{\text {nd }}$ and $34^{\text {th }}$, once again 33 observations, but with a new group of data. Finishing that procedure, 14 frames are constructed; the last frame is constructed by taking data between $14^{\text {th }}$ and $46^{\text {th }}$ observations. As there are $5+1$ number of banks, and the correlation is calculated in pairs, $\mathrm{C}(6,2)=15$ correlations are calculated for the first frame. The 15 correlations are calculated for every 14 frames resulting in 210 correlations altogether. Figures 2-6 show the time effect on the correlation.

Table 2. Correlation Table

\begin{tabular}{|l|c|c|c|c|c|}
\hline & Albaraka Turk & Kuveyt Turk & Turkiye Finans & Vakif Katilim & Ziraat Katilim \\
\hline Albaraka Turk & 1 & & & & \\
\hline Kuveyt Turk & 0.98 & 1 & & & \\
\hline Turkiye Finans & 0.99 & 0.97 & 1 & & \\
\hline Vakif Katilim & 0.99 & 0.99 & 0.99 & 1 & \\
\hline Ziraat Katilim & 0.98 & 0.99 & 0.97 & 0.98 & 1 \\
\hline Central Bank & 0.90 & 0.94 & 0.89 & 0.90 & 0.93 \\
\hline
\end{tabular}

Source: authors.

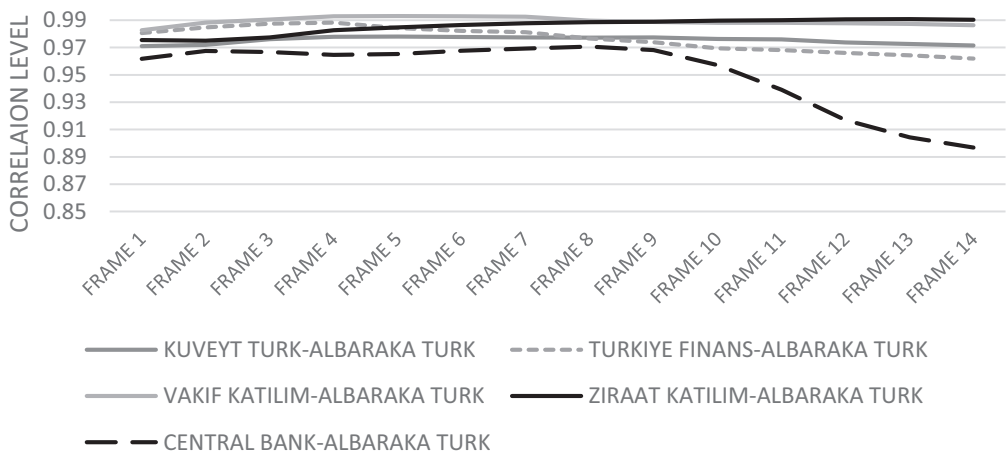

Source: authors.

Fig. 2. Albaraka Turk historical correlation analysis 


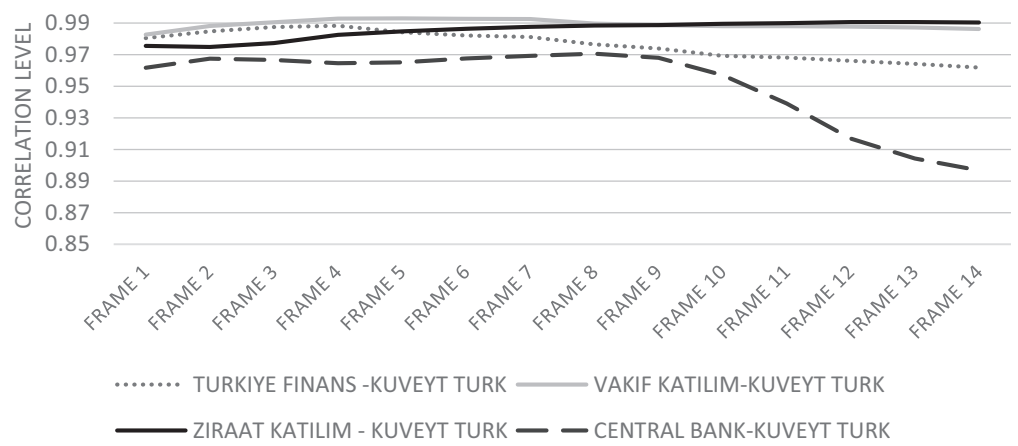

Source: authors.

Fig. 3. Kuveyt Turk historical correlation analysis

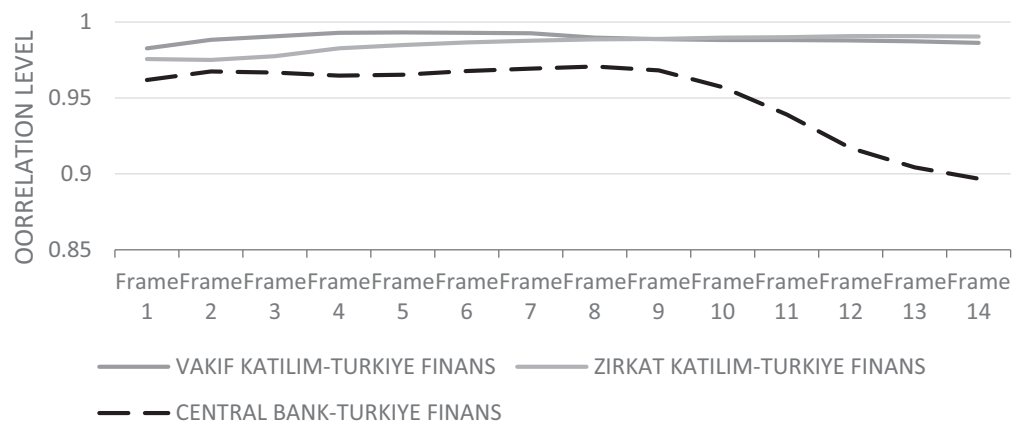

Source: authors.

Fig. 4. Turkiye finans historical correlation analysis

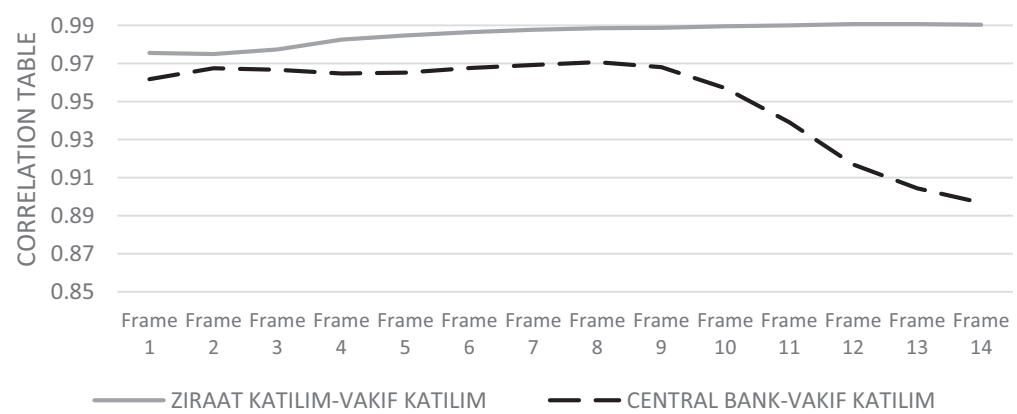

Source: authors.

Fig. 5. Vakif katilim historical correlation analysis 


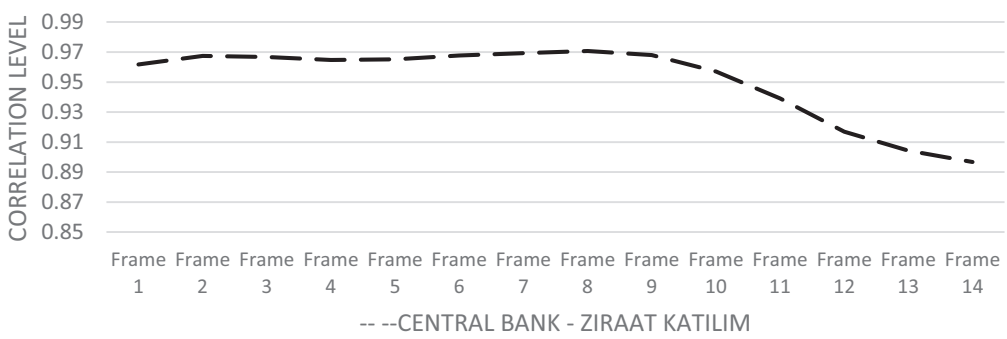

Source: authors.

Fig. 6. Ziraat katilim historical correlation analysis

Figures show that all correlations are high, all around 0.90 or above. They also indicate that the correlation between the monthly weighted average interest rates applied to banks' deposits by the Central Bank and other banks was above 0.95 before the $10^{\text {th }}$ period. However, this correlation starts to decrease below 0.9 after the $10^{\text {th }}$ frame. Therefore, it can be concluded that the association between the monthly weighted average interest rates applied to banks' deposits by the Central Bank is strong. Although, it does shows some volatility.

Besides correlation, wavelet coherence enables us to identify the lead-lag relations between two time series. Figure 7 displays the results of wavelet coherence between the participation bank's profit-loss sharing ratios and the average conventional bank deposit rates.

The magnitude-squared wavelet coherence coefficient can be regarded as a local linear correlation measure between two-time series in the time-frequency space. Wavelet coherence with a phase difference (we call this "lag-period" hereinafter) is plotted for each participation bank. Magnitude-squared coherence values close to one represent the high coherence level. As in usual coherence displays, these high correlations are marked in a yellow-orange color ("warm colors"). When there is a low or no correlation found, it is marked in blue ("cold colors").

Where coherence exceeds 0.5 , we also focus on the phase from the wavelet cross-spectrum to detect the relative lag signed by arrows. For the monthly data, instead of frequencies, we took the oscillations in terms of periods of years (the lag-periods) shown on the left axes in each of the figures. When there is a zero phase-difference, it indicates that the time series move together. The arrows pointing right imply that the movement of the series is the same, and the correlation is positive. The arrows pointing left mean that the profit-sharing ratios and Central Bank interest rate move in the opposite direction, showing a negative correlation. When the arrows point up, it means that the first time series (in our analysis, the participation banks' profitsharing ratios) leads the second one (the central bank deposit rate) with a time lag. On the other hand, when the arrows are showing down, they indicate that the second series lead the first one. The key area is within the dashed white contour where edge effects are regarded as significant.

Figure 7 illustrates time-localized areas of strong coherence occurring in the different lag-periods. It shows that generally there is coherence between participation banks' profit ratios and deposit rates displayed in the figures. The yellow area and the arrows especially in the region of 1.02.0 lag-period (left axes) prove the existence of the high coherence and the impact of the time series.

At around 0.5-year lag-period (at around 0.5 on left axes), results are more diverse. Figure 7 shows that at the beginning of the 4-year-long period, there is a high coherence for all participation banks. The arrows pointed right in the yellow region show that the correlation is 

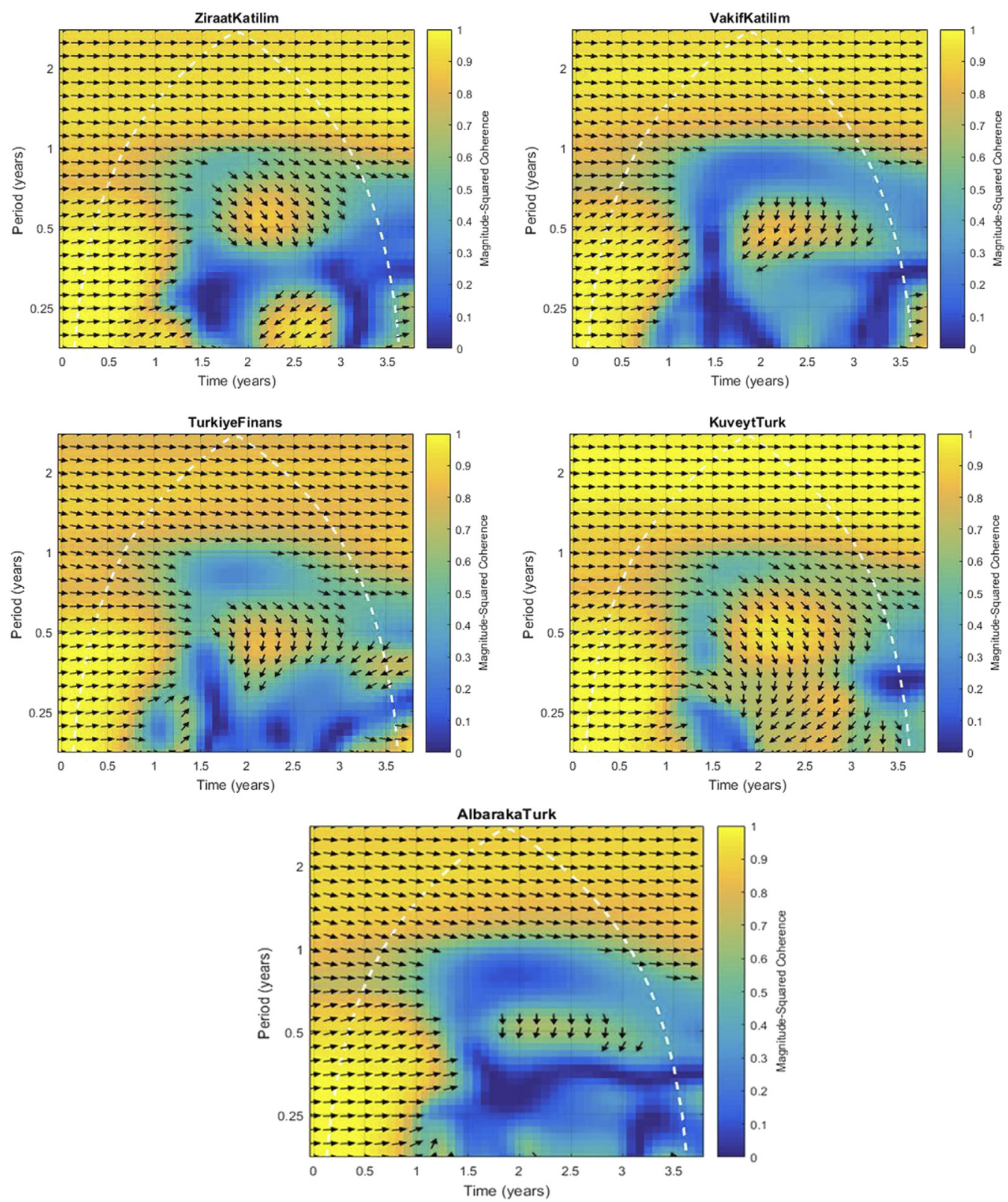

Source: authors.

Fig. 7. Wavelet results

generally positive. Some of the arrows point also slightly upwards, assuming a possible lead of profit-sharing ratios on the deposit rate; however, the effect seems to be very low. After about 1.5 years the arrows clearly point downwards as a sign of lag between the time series, showing more 
convincingly that the movements of interest rates lead the changes in profit-loss ratios of participation banks.

The results based on time (horizontal axis) generally confirm the main conclusions of the historical correlation analysis. The correlation is highly positive until the end of the $12^{\text {th }}-15^{\text {th }}$ month (until June 2017), and after that the correlations decrease. On the other hand, the wavelet technique shows some differences among banks. Kuveyt Turk's participation rates are the most coherent with the interest rate. The profit-sharing ratios of Albaraka Turk and Vakif Katilim shows the least coherence with conventional banking interest rates from around 1.5 years, when the lag-period of the analysis is less than 1 year. In this region the direction of the association is clearer; the interest rates lead the profit share ratios of all the five banks after about the $20^{\text {th }}$ month. There are small differences in the time lag of the two series among the banks. In the case of Turkiye Finans and Kuveyt Turk, the time lag seems to be shorter, less than 6 months, as if these banks reacted to the interest rate changes a few months quicker than the other banks, where the time-lag effect could only be identified (high coherence with arrows pointing downwards) typically at a lag-period of around 0.5 years.

Despite these differences, in general, all five banks show similarities in how coherence changes at the 0.5 -year lag-period level: profit rates show high coherence until the $15^{\text {th }}$ month, low coherence between the $15^{\text {th }}$ and $20^{\text {th }}$ month, visibly higher coherence between the $20^{\text {th }}$ and $35^{\text {th }}$ month, and lower coherence in the last few months again.

\section{CONCLUSIONS}

The success of Islamic finance depends on the justifiable differentiation of the profit-loss shares from market interest rates. The high correlation and the co-movements between the two rates may harm people's trust in the Islamic finance sector. Most of the studies of the international and the Turkish banking sector supported the idea that there was a strong dynamic and conditional association between the interest rates and profit shares. We followed the focus of these papers using the latest data, since participation banks have become more relevant. Furthermore, we applied methodologies that have not been used to analyze the association in this market yet.

Historical correlation analysis of the five dominant participation banks' profit ratios and the deposit rate of the central bank supports the results in the literature of a strong correlation, but also shows that there is a change, a decrease in the correlation after the $10^{\text {th }}$ frame. The wavelet analysis illustrates the coherence of the monthly rates. It shows that participation bank profit ratios are generally positively correlated and highly coherent with the interest rates, especially in the region of the 1.0-2.0 lag-periods. It also shows a high coherence with a lag-period less than 1.0 year until the $15^{\text {th }}$ month. Focusing on the lag-period of about 0.5 , calculations show not only the positive correlation but also that the interest rate generally leads the profit-sharing ratios. However, there are small differences among the banks concerning the level of coherence, how long the lag-periods are, and how quickly the profit-sharing ratios follow the changes of the central bank's interest rates. It would be worth studying these differences more in detail by extending the time horizon of the analysis in a later study.

Summing up, our research confirms the general findings of previous papers on the Turkish and other Islamic banking markets. Although it is claimed that profit-sharing ratios are different from interest rates paid on the deposits of conventional banking, they are generally highly 
correlated. However, we find small differences among participation banks in the level of coherence and the time lags, and how quickly the changes in profit-sharing ratios follow the market interest rate changes. Nevertheless, the clear existence of an association between interest rates and profit-sharing ratios can result in investors questioning whether Islamic banks truly follow the rules required by religion, and it can destruct investors' trust in Islamic banking.

\section{REFERENCES}

Ahmad, N. H. - Ahmad, S. N. (2004): Key Factors Influencing Credit Risk of Islamic Bank: A Malaysian Case. Journal of Muamalat and Islamic Finance Research 1(1): 65-80. https://doi.org/10.33102/jmifr.

Anuar, K. - Mohamad, S. - Shah, M. (2014): Are Deposit and Investment Accounts in Islamic Banks in Malaysia Interest-Free? Journal of King Abdulaziz University: Islamic Economics 27(2): 29-58. https:// doi.org/10.4197/islec.27-2.2.

Athanasoglou, P. - Delis, M. - Staikouras, C. (2006): Determinants of Bank Profitability in the South Eastern European Region. Journal of Financial Decision Making 2(2): 1-17.

Aysan, A. F. - Ozturk, H. (2018): Does Islamic Banking Offer a Natural Hedge for Business Cycles? Evidence from a Dual Banking System. Journal of Financial Stability 36: 22-38. https://doi.org/10.1016/j. jfs.2018.02.005.

Azad, A. S. - Azmat, S. - Chazi, A. - Ahsan, A. (2018): Can Islamic Banks Have Their Own Benchmark? Emerging Markets Review 35: 120-136. https://doi.org/10.4324/9781315606088-10.

Azmat, S. - Azad, A. S. - Bhatti, M. I., - Ghaffar, H. (2020): Islamic Banking, Costly Religiosity, and Competition. Journal of Financial Research 43(2): 263-303. https://doi.org/10.1111/jfir.12207.

Azmat, S. - Azad, A. S. - Ghaffar, H. - Bhatti, I. (2015): Why Interest-free Islamic Banking is Not Free from Interest? https://www.deakin.edu.au/_data/assets/pdf_file/0003/392295/islamic-banking-notfree-from-interest-Azmat-Azad-Ghaffar-and-Bhatti.pdf, accessed 04/04/2021.

Bashir, A. H. M. (2001): “Assessing the Performance of Islamic Banks: Some Evidence from the Middle East". Topics in Middle Eastern and North African Economies 3.

BDDK (2019): Turk Bankacilik Sektoru Temel Gostergeleri https://www.bddk.org.tr/ContentBddk/ dokuman/duyuru_0789_01.pdf, accessed 15/01/2021.

Chen, B. - Masih, M. (2017): Are the Islamic and Conventional Money Markets Really Highly Correlated? MGARCH-DCC and Wavelet Approaches. MPRA Paper 79886.

Chong, B. S. - Liu, M. H. (2009): Islamic Banking Interest-Free or Interest-Based. Pacific-Basin Finance Journal 17: 125-144. https://doi.org/10.2139/ssrn.868567.

Dar, H. A. - Presley, J. (2000): Lack of Profit Loss Sharing in Islamic Banking: Management and Control Imbalances. Department of Economics Research Paper No. 00/24.

Dinc, Y. (2017): Islamic Price Index Offer and Effects of Consumer Price Index on Islamic Banks. Journal of Emerging Issues in Economics, Finance and Banking (JEIEFB) 6(1): 2044-2063.

Dinç, Y. (2016): Katılım bankalarının danışma kurullarının kurumsal yönetim unsuru olarak değerlendirmesi. Islam Ekonomisi ve Finans Dergisi 2: 83-103.

El Gamal M.A. (2006): Islamic Finance: Law, Economics and Practice. New York: Cambridge University Press.

Elgari M. A. (2003): Credit Risk in Islamic Banking and Finance. Islamic Economic Studies 10(2): 1-15.

Ergeç, E. H. - Arslan, B. G. (2011): Impact of interest rates on Islamic and conventional banks: the case of Turkey. Applied Economics 45(17): 2381-2388. https://doi.org/10.1080/00036846.2012.665598. 
Ferhi, A. (2018): "Credit Risk and Banking Stability: A Comparative Study between Islamic and Conventional Banks". International Journal of Law and Management 5(3): 1000193. https://doi.org/10.4172/2375-4516. 1000193.

González C. C. - Gil Fariña, M. C. - Pestano G. C. (2012): Using Wavelets to Understand the Relationship between Mortgages and Gross Domestic Product in Spain. Journal of Applied Mathematics 2012: 917247. https://doi.org/10.1155/2012/917247.

Hamrita, M. - Trifi, A. (2011): The Relationship between Interest Rate, Exchange Rate and Stock Price: A Wavelet Analysis. International Journal of Economics and Financial Issues 1: 220-228.

Hassoune, A. (2002): "Islamic Banks' Profitability in an Interest Rate Cycle". International Journal of Islamic Financial Services 4(2): 1-13.

Jiang, Z. - Yoon, S. M. (2020): "Dynamic Co-Movement between Oil and Stock Markets in Oil-Importing and Oil-Exporting Countries: Two Types of Wavelet Analysis". Energy Economics 90: 104835. https:// doi.org/10.1016/j.eneco.2020.104835.

Khan, M. S. (1986): "Islamic Interest-Free Banking: a Theoretical Analysis". IMF Staff Papers 33(1): $1-27$.

Khan, T. - Ahmed, H. (2001): Risk Management: An Analysis of Issues in Islamic Financial Industry. Islamic Research and Training Institute Occasional Papers 91.

Khoufi, W. (2018): Contagion between Islamic and Conventional Banks in Malaysia: Empirical Investigation Using a DCC-GARCH Model. Journal of King Abdulaziz University: Islamic Economics 31(1): 167-178. https://doi.org/10.4197/Islec.31-1.11.

Koç, İ.M. (2018): Interest Rate Risk in Interest-free Banks: An Empirical Research on Turkish Participation. Turkish Journal of Islamic Economics 5(1): 89-107. https://doi.org/10.26414/tujise.2018.5.1. 89-107.

Latifa, B. M. - Khoufi, W. (2018): "Contagion between Islamic and Conventional Banks in Malaysia: Empirical Investigation using a DCC-GARCH Model”. Journal of King Abdulaziz University, Islamic Economics 31(1): 167-180. https://doi.org/10.4197/Islec.31-1.11.

Moody's (2020): "Research Announcement: Turkish Islamic Banking set for Fast Growth after Slow Start”. http://www.moodys.com/researchdocumentcontentpage.aspx?docid=PBC_1174638, accessed 19/07/ 2021.

Moya-Martínez, P. - Ferrer-Lapena, R. - Escribano-Sotos, F. (2015): Interest Rate Changes and Stock Returns in Spain: A Wavelet Analysis. BRQ Business Research Quarterly 18(2): 95-110. https://doi.org/ 10.1016/j.brq.2014.07.004.

Okumuș, Ș. H. (2005): "Interest-Free Banking in Turkey: A Study of Customer Satisfaction and Bank Selection Criteria". Journal of Economic Cooperation 26: 51-86.

Pal, D. - Mitra, S. (2017): “Time-Frequency Contained Co-Movement of Crude Oil and World Food Prices: A Wavelet-Based Analysis". Energy Economics 62: 230-239. https://doi.org/10.1016/j.eneco.2016.12. 020.

Reboredo, J. C. - Rivera-Castro, M. A. - Ugolini, A. (2017): “Wavelet-Based Test of Co-Movement and Causality between Oil and Renewable Energy Stock Prices". Energy Economics 61(C): 241-252. https:// doi.org/10.1016/j.eneco.2016.10.015.

Saraç, M. - Zeren, F. (2015): "The Dependency of Islamic Bank Rates on Conventional Bank Interest Rates: Further Evidence from Turkey". Applied Economics 47(7): 669-679. https://doi.org/10.1080/00036846.2014. 978076.

Shaukat, M. (2014): Wavelet Analysis of Deposit returns. Conventional and Islamic Contingency: The Malaysian Saga. Journal of Islamic Banking and Finance 3(2): 67-82. 
Sorwar, G. - Pappas, V. - Pereira, J. - Nurullah, M. (2016): "To Debt or not to Debt: Are Islamic Banks Less Risky than Conventional Banks?” Journal of Economic Behavior - Organization 132(1): 113-126. https://doi.org/10.1016/j.jebo.2016.10.012.

TBB (2020): TBB Data System, The Banks Association of Turkey. https://verisistemi.tbb.org.tr/, accessed $18 / 09 / 2020$.

Vong, A.P.I. - Chan, H.S. (2006): Determinants of Bank Profitability in Macao. Monetary Authority of Macao, Macao Monetary Research Bulletin Quarterly Publication 12(1): 94-113.

Warninda, T. D. - Ekaputra, I. A. - Rokhim, R. (2019): "Do Mudarabah and Musharakah Financing Impact Islamic Bank Credit Risk Differently?” Research in International Business and Finance 49(1): 166-175. https://doi.org/10.1016/j.ribaf.2019.03.002.

Yilmaz, A. - Güneş, N. (2015): "Efficiency Comparison of Participation and Conventional Banking Sectors in Turkey Between 2007-2013”. Procedia-Social and Behavioral Sciences 195(1): 383-392. https://doi. org/10.1016/j.sbspro.2015.06.338.

Yüksel, S. - Canöz, İ. - Ozsari, M. (2017): Causality Relationship between Interest Rate of Deposit Banks and Profit Share Rate of Islamic Banks in Turkey. Journal of Islamic Economics and Business 2(2): 131148. https://doi.org/10.24042/febi.v2i2.1894.

Zhao, Y - Laguna, R. C. - Zhao, - Liu, J. J. - He, X. - Yianni, J - Sarrigiannis, P G. (2018): A Wavelet-Based Correlation Analysis Framework to Study Cerebromuscular Activity in Essential Tremor. Advanced Methods to Analyse the Complexity of the Brain 2018: 7269494. https://doi.org/10.1155/2018/7269494.

Zineldin, M. (1990): The Economy of Money and Banking: A Theoretical and Empirical Study of Islamic Interest-free Banking. Stockholm: Almqvist - Wiksell International.

Open Access. This is an open-access article distributed under the terms of the Creative Commons Attribution 4.0 International License (https://creativecommons.org/licenses/by/4.0/), which permits unrestricted use, distribution, and reproduction in any medium, provided the original author and source are credited, a link to the CC License is provided, and changes - if any - are indicated. (SID_1) 